\title{
The thymic education of developing $T$ cells in self neuroendocrine principles
}

\author{
V. Geenen, F. Robert, H. Martens, D. De Groote*, and P. Franchimont \\ Institute of Pathology B-23, Laboratory of Radio-Immunology, University Hospital of Liège-Sart Tilman, \\ B-4000 Liège, *Medgenix Diagnostics, B-6220 Fleurus, Belgium
}

\section{INTRODUCTION}

The thymus is now recognized as the primary lymphoid organ involved in the differentiation of Tlymphocytes (1). In the human species, its physiological role seems to be mainly exerted along fetal development since congenital thymic hypo- or aplasia (like in the Di George's syndrome) is followed by a profound impairment of T cell functions, leading to the premature death of the child. On the contrary, ablation of the human thymus after birth is not followed by significant immune deficiency. T cell ontogeny is a highly complex process which can be divided in several distinct phases. Firstly, T cell precursors originating from the fetal liver and bone marrow migrate through separate waves into the thymic rudiment, most probably under the influence of specific chemoattractants (2). Secondly, within the thymus, immature $T$ cells undergo rearrangement of the genes coding for the chains of their receptor for antigen (TcR), and express differentiation markers (CDs) at their surface. These processes are not purely automatic, but are intimately controlled by the thymic microenvironment (epithelial cells, macrophages, dendritic or interdigitating cells, and flbroblasts) (3). Thirdly and importantly, the thymus is the site for the negative selection of self reactive $T$ cells and this mechanism is basically responsible for the induction of $T$ cell self tolerance (self/non-self discrimination) (4-6).Finally, the integration by target pre-T cells of the various differentiative signals (adhesion molecules, growth factors, and cytokines (7)) encountered in the thymus leads to the positive selection of mature immunocompetent T lymphocytes (8).

Key-words: Cryptocrine signalling, thymus, neuroendocrine self antigen, antigen recognition, self tolerance, autoimmunity, positive selection.

Correspondence: Vincent Geenen, M.D., Ph.D., Research Associate of Belgian FNRS, Laboratory of Radio-Immunology B-23, NeuroendocrinImmunology Unit, University Hospital of Liège-Sart Tilman, B-4000 Liège, Belgium.

\section{CELL-CELL INTERACTIONS IN THE THYMUS}

Thymic epithelial cells (TEC) constitute the major component of the environment controlling $T$ cell differentiation (9). They have a mixed, ectodermal and endodermal, origin $(10,11)$. The endoderm derives from the third pharyngeal pouch, while the ectoderm originates from the cervical and from the third branchial cleft. The majority of cortical TEC seem to derive from the endoderm, whereas the ectoderm would contribute to the subcapsular cortical epithelium, some stellate cortical cells, the medullary epithelium and the Hassall's corpuscles. Since Le Douarin's pioneering studies (12), it is well acknowledged that the cephalic neural crest exerts an important influence upon thymic organogenesis, even if the exact contribution of neural crest migrants in the thymus is still discussed. TEC of the subcapsular cortex and medulla also share common immunocytochemical characteristics, like their labelling with antisera directed against thymic peptides (anti-thymosin $\alpha 1$ (13) and anti-thymulin (14)) or with monoclonal antibody (mAb) A2B5 (which reacts with complex gangliosides found in the brain and the diffuse neuroendocrine system) (15). We have also demonstrated that the same subsets of TEC contain neurohypophysial (NHP)-related peptides and immunoreactive (ir) interleukin-1B (IL-1B) $(16,17)$. Thymic nurse cells (TNC) are large epithelial cells which can be isolated by $1 \mathrm{~g}$ sedimentation from murine thymuses after enzymatic digestion (18), and which have been identified in situ in the thymic subcapsular and outer cortex $(19,20)$. TNC were also shown to synthetize NHP-related peptides, and to express the same immunophenotype as cellular elements belonging to the diffuse neuroendocrine system (21).

Even if the thymus has been considered for many years to be an intrinsic component of the endocrine system, the pattern of secretion in TEC is rather different from the classical endocrine secretory process (22). We have also demonstrated that the classical scheme of neurosecretion established for the 
hypothalamo-NHP axis could not be applied to the thymic cell-to-cell signalling. The concept of cryptocrine signalling (23) was recently introduced by J.W. Funder to describe the exchange of informations in secluded microenvironments created by large epithelial cells enclosing migratory developing cells. Two examples at least of cryptocrine signalling exist in the human body: one in the thymus, between TEC/TNC and immature T cells (pre-T cells or thymocytes); another in the testis, between Sertoli cells and spermatids. Interestingly, Sertoli cells have already been described in 1899 as "nurse" cells essential for the germinal cell and the process of spermatogenesis (24). In the thymus, the mitotic index of TNC-engulfed thymocytes is rather high and recent studies have evidenced that TEC/TNC can present antigen+self major histocompatibility complex (MHC) (25). Consequently, it seems highly probable that TNC display the biochemical machinery to actively intervene in the selective process of $T$ cells (26). The tolerogenic properties of TEC have also been illustrated in several experimental paradigms (27-29). On the basis of our observations, we have proposed that thymic NHP-related peptides could serve as functional signals in cryptocrine communication between TEC/TNC and pre-T cells (30). The analogy between TNC and testicular Sertoli cells is further supported by the recent observation of the expression of an oxytocin (OT) gene in cattle Sertoli cells (31), as well as by the immuno-labelling of human Sertoli cells with mAbs A2B5 and $\mathrm{O} 33$ (directed against the cyclic part of OT (32)) (unpublished observations). If the molecular mechanisms underlying the intrathymic expression of NHP-like peptides remain to be further characterized, separate studies have confirmed the presence in the thymus of immunoreactive and bioactive OT-like peptide (33-35). Furthermore, the expression of functional NHP peptide receptors by rat thymocytes (36) and by murine immature and differentiated $T$ cells is a prerequisite in favor of this working hypothesis (37). Since the intrathymic concentrations of NHP-related signals are in good concordance with the high affinity Kd of NHP receptors expressed by pre-T cells, the physico-biochemical conditions are encountered to render effective in vivo a thymic cryptocrine signalling through NHP peptides and their cognate receptors. This is obviously not the case for circulating neurohormones OT and VP, due to their low blood concentrations. The pre-T cell NHP receptors were shown to mediate mitogenic properties of NHP-related signals upon human and murine pre-T cells. Their transductory properties involve a $T$ cell phosphoinositide breakdown and were similar to those described for other V1/OT re- ceptors. This effect was specifically inhibited by a $\mathrm{V} 1$ antagonist in pre-T cells and by an OT antagonist in cytotoxic T cells (37). This shift in the type of $T$ cell NHP receptor may suggest a dynamic phenomenon of molecular maturation parallel to the progress of $T$ cells in their differentiative programme. As evidenced by our previous radiobinding studies (38), the $V 1$ receptor expressed by pre$\mathrm{T}$ cells is probably an immune-specific V1 subtype different from the recently cloned V1a receptor (39). In the murine species, other authors have also reported the expression of a novel V1 subtype by splenic cytotoxic lymphocytes (40). Of course, the TNC-derived NHP signals are not the only growth factors implicated in T cell differentiation, but their mitogenic properties evidenced on pre-T cells may provide an explanation to the high mitotic index of TNC-engulfed thymocytes. They also demonstrate an implication of thymic NHP-related peptides in the process of $\mathrm{T}$ cell positive selection, in accordance with previous observations (41). Molecular disturbances of cryptocrine signalling might also intervene in pathologic states, either at the level of NHP signal (thymoma are the third cause of inappropriate VP secretion $(42,43)$ ), or at the level of NHP receptor (with potential implication in T cell lymphoma oncogenesis). Interestingly, the intervention of TNC in leukemogenic process have already been demonstrated before (44). The expression of NHP peptide receptors by immune cells also opens novel immunomodulatory strategies through the molecular design of neuropeptide immune-specific receptor antagonists or agonists. We recently described a significant inhibition by novel OT nonpeptide antagonists (Merck Sharp \& Dohme Research Laboratories, West Point) of IL-1B, IL-6 and TNF $\alpha$ productions in human whole blood cell cultures stimulated by anti-CD3 mAb (45). This inhibition was significantly more important in whole blood cell cultures derived from human female volunteers, suggesting an influence of the gonadal steroid hormonal environment. The future knowledge of the precise NHP receptor subtypes expressed by immunocompetent cell populations should help computer modelling and molecular engineering of speciflc immunomodulatory compounds based on the basal structure of these OT cyclic hexapeptide antagonists. This approach could lead to selective immunotherapy in crucial life periods, such as the postpartum, during which an immune disequilibrium is determined by an increase of the oestrogen/progesterone ratio and by a rise in immunostimulatory lactogenic hormones prolactin and OT.

Within cryptocrine microenvironments, the sense of 
chemical information may also be directed from the engulfed developing cells to the large epithelial "nursing" cell. This seems to be the case with nerve growth factor (NGF) since this was shown to be synthesized by male germ cells (46), whereas NGF receptor was shown to be expressed by Sertoli cells (47). An analogous situation may exist within thymic microenvironment as NGF receptor mRNA was also detected in chick and rat thymus extracts (48), but the precise source of the thymic NGF signal remains to be further defined. Of high relevant interest with regard to the role of NGF in thymic physiology is the recent observation that this neurotrophic factor markedly enhances the molecular and phenotypic neuronal-like features of cultured murineTEC (49).

\section{T CELL RECOGNITION OF SELF NEUROENDOCRINE FUNCTIONS}

Neurohypophysial (NHP) peptide family

Through the use of several well-characterized polyclonal and mAbs, we have defined the immunodominant epitopes representative of the NHP peptide family expressed by TEC/TNC of several animal species (50). The first epitope is located, at least partially, in the six amino acid cyclic part shared by OT and by vasotocin (VT), the ancestral peptide precursor of the NHP family constituted by the cyclic part of OT and the three amino acid lateral chain of VP. The second epitope is present in the central "constant" part of the neurophysin domain. This part is encoded by the second exon of NHP genes and show a high degree of conservation $(>90 \%)$ throughout the evolution of species whichever the nonapeptide associated (51). In the overall evolution of intercellular communication, the cryptocrine stage evidenced in the thymus introduced an obligatory step which is the recognition of the self molecular structure by developing $T$ cells. This would logically follow the presentation by thymic MHC molecules of self epitopes representative of larger proteins. The size of the $\mathrm{MHC}$ groove allows the binding of peptide sequences ranging from a minimum of five (52) to seventeen amino acids in length (53). If demonstrated, the presentation by thymic MHC molecules of the NHP self epitopes could therefore induce the central immune tolerance of hypothalamo-NHP functions. This tolerogenic effect would result from the clonal deletion of highly reactive $T$ cells harboring a randomly rearranged $\mathrm{TCR}$ specific for the association $\mathrm{MHC} /$ self NHP epitope(s). The large involvement of OT-like peptides at different levels of the reproductive processes implies that they are strongly tol- erated by the immune system. This high tolerance of OT lineage protects it from a potential autoimmune aggression and would therefore contribute to the preservation of the species. Since VP differs from NHP self epitope by one single amino acid in its cyclic part, it is less "protected" from autoimmune process. Indeed, some authors have previously reported "idiopathic" diabetes insipidus resulting from autoimmune aggression directed against hypothalamic magnocellular neurones (54). In the same view, experimental breakdown of NHP immune tolerance by active immunization against VP was also shown to induce inflammatory lesions in the hypothalamo-NHP axis (55). It is also interesting to note that the frequence and the titers of antisera against VP are usually higher than those of antisera developed against OT or VT.

So, the deep investigation of our original observations (56) led us to shift from the classical neurosecretion model to the novel pathways underlying cryptocrine cell-to-cell signalling and self antigen presentation by $\mathrm{MHC}$ molecules. At the molecular level, the "neuropeptide" model was replaced by the working concept of NHP "self peptide" $(57,58)$. As discussed before, thymic NHP-related self peptides exert a dual role in $\mathrm{T}$ cell differentiation according to the type of intercellular dialogue in which they are engaged (cryptocrine signalling or NHP self antigen presentation by thymic $\mathrm{MHC}$ ).

\section{Tachykinin (TK) peptide family}

This model of a dual physiological role for thymic self peptides also applies to this family whose intrathymic expression was investigated in collaboration with the Laboratory of Molecular Neurobiology at the Karolinska Institute (Stockholm). Neurokinin A (NKA) is the TK peptide encoded by preprotachykinin-A (PPT-A) gene in the rat thymus (59) and is thus the first member of the TK family encountered by developing T cells. Mitogenic activities have been described for NKA and physalaemin upon murine cultured thymocytes (IL-1-like bioactivity), while substance P (SP) and other TK-related peptides did not exert any significant effect (60). These observations strongly support the involvement of thymic NKA in T cell positive selection. Since NKA shares with other TKs the same C-terminal immunodominant epitope, it might represent the tolerogenic TK peptide that is expressed in the thymus and is facing the developing T cell system. The other TK peptide SP detected in rat and human thymic extracts is associated with sensory nerve fibers and seems to be implicated in the regulation of thymic blood flow $(61,62)$. This does not exclude that SP exerts peripheral 
proinflammatory properties, however through specific immune TK receptors since potential TK autoreactive $T$ cells would have been deleted in the thymus.

\section{Insulin peptide family}

Insulin-like growth factors (IGFs) were also identified within the human fetal thymus, both at the peptide and mRNA levels $(63,64)$.

However, these studies could not really discriminate between IGF-I or IGF-II, and the thymic subcellular localization remains to be further defined because of the discrepancies observed between the localizations of IGF mRNAs and immunoreactivities. The fact that thymic IGFs are implicated as accessory signals in T cell positive selection is indirectly suggested by the mitogenic properties of IGF-I on pre-T thymic lymphoma cells (65). The activation of human $T$ lymphocytes by anti-CD3 also leads to their expression of IGF-I and IGF-II receptors (66). Due to the high homology ( $\pm 60 \%$ ) of proinsulin and IGFs primary amino acid sequences, the tolerance of pancreatic endocrine function could result from the intrathymic deletion of $\mathrm{T}$ cells harboring a rearranged TcR specific of the association thymic $\mathrm{MHC} / \mathrm{insulin}$ family self epitopes. The IGF-II region on chromosome $11 \mathrm{p}$ seems also to be involved in HLA-DR4-dependent diabetes susceptibility by a still undefined molecular mechanism (67). So, further characterization of the precise insulin/IGF-derived self immunodominant epitope expressed in the human thymus should lead to the identification of the primary self antigen implicated in the autoimmune cascade leading to overt insulindependent diabetes. In another connection, several antigenic markers are shared between TEC/TNC, and pancreatic islet B-cells, among which A2B5 and HISL (68). This cellular phenotypical relationships may suggest a common embryonic origin in the neurectoderm or in the neural crest (69).

\section{Other members of the thymic peptide repertoire}

Several neuroendocrine peptides have been detected in the thymus from various species, at the peptide or the mRNA level (70-75). In two of these studies, neuropeptides were ultrastructurally detected in perinuclear space, vesicular structures and rough endoplasmic reticulum, but not in classical secretory granules. Since an atrial natriuretic peptide (ANP) signal is found in thymic stroma and that ANP receptors are also expressed by rat thymocytes, a functional accessory signalling through this peptide should also be further investigated in the process of T cell development (76). An au- tocrine/paracrine signalling through luteinizing hormone-releasing factor ( $\mathrm{LHRH}$ ) seems also to intervene in the modulation of the $\mathrm{T}$ cell differentiation pathways $(77,78)$. Parathormone-related peptide (PTH-RP), as well as calcitonin gene-related peptide (CGRP) were also recently found to be included in the thymic self peptide repertoire $(79,80)$. Both of these polypeptides shared common amino acid sequences with the hormonal members (PTH and $\mathrm{CT}$ ) of their corresponding family and could therefore induce $\mathrm{T}$ cell tolerance of PTH- and CTmediated endocrine functions.

\section{NEURAL AND ENDOCRINE CONTROLS OF THYMIC FUNCTION}

Like all peripheral organs, the thymus receives autonomic sympathetic and parasympathetic innervation $(81,82)$. A number of neuropeptides have also been identified in sensory nerve fibers of the thymus (83). At the present time, it is however still difficult to establish whether these innervations exert a control upon thymic stromal cells, thymic blood flow or may directly act upon differentiating $T$ cells.

The thymic physiological role is also closely influenced by the endocrine environment, in particular by thyroid (84) and antehypophysial hormones (85), as well as by gonadal steroids and glucocorticoids $(86,88)$. There is increasing evidence that these hormonal influences may be relayed by intrathymic factors (i.e. the trophic role of growth hormone upon the thymus (89) is most probably mediated by local actions of thymic IGF-I). To our knowledge, the existence of a specific antehypophysial thymotrophin has never been investigated but this question deserves further attention given the intimate relationships between the thymus and the pituitary (90).

\section{CONCLUSIONS}

The ontogenetical and phylogenetical evolutions of the endocrine system have seen the emergence of various forms of intercellular communication, from the most primitive stages of autocrine signalling (when a cell is alone) and adhesion (which follows the division of one cell) to the most complex neurocrine networks underlying cognitive processes in the central nervous system. Parallel to the successive structural levels of the evolution of intercellular communication, it appeared some hierarchy in the genomic organisation responsible for the transfer of biochemical information between cell populations (91). In recent years, new members of en- 
docrine families were identified through the use of molecular techniques. These factors were not classical "hormones" vehiculated by bloodstream, but rather exerted local growth-promoting "paracrineautocrine" activities. It also appeared that these tissue peptide growth factors were predominantly expressed during fetal life and were playing an important role in embryo development and organogenesis. Their etiopathogenic involvement in neoplasic processes is more and more documented, and their gene overexpression is sometimes followed by a massive release in bloodflow. A paraneoplasic syndrome may then follow, due to the usual cross-reactivity of these tissue growth-factors with the relative hormone receptors. On the other side, the immune system has evolved, the primary characteristic of which is the protection of the self molecular structure against foreign infectious invaders (non-self). The thymus is one crucial privileged site for which appears as an obligatory step in the parallel evolutions of neuroendocrine and immune systems: the education of T cells to discriminate self antigens and foreign (non-self) antigens. In the line of that highly simplified perspective, the incidental breakdown of self immune tolerance as seen in autoimmune pathologies may be considered as the global tribute paid by one given species for its protection against infectious non-self antigens.

In the actual stage of our research on the neuroendocrine self peptide repertoire expressed in the thy-

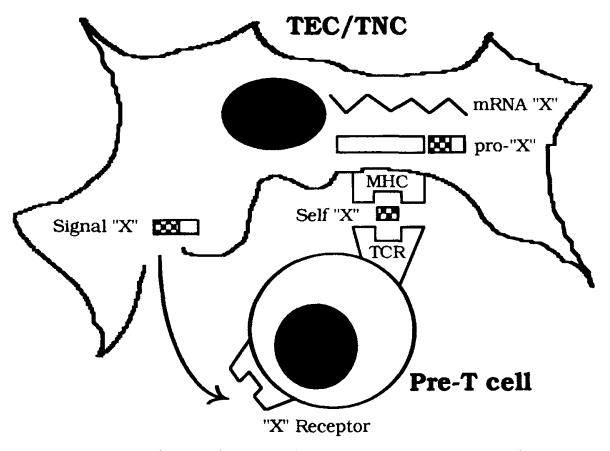

\section{Cryptocrine signalling}

Physiology

Accessory signal in $\mathrm{T}$ cell differentiation/activation

Pathophysiology \& Pharmacology Paraneoplasic syndromes(signal "X") Oncogenesis ("X" receptor) Immunomodulation by

"X" receptor agonists/antagonists

Fig. 1 - Thymic education of T cells in self neuroendocrine principles: model of the dual physiological role of thymic self peptides in T cell differentiation. mus, this primary lymphoid organ appears more and more as a highly specialized school for the education of T cells in self neuroendocrine principles (Fig. 1). In the human species, that school is mainly working during fetal development and its highest educational degree is the apoptosis of the autoreactive T cells (92). A failure in the educational programme would result in the emergence of T cells with autoreactivity directed against neuroendocrine self antigen(s), and this point could play an important pathogenetic role in endocrine autoimmune diseases. Of course, the appearance of autoreactive T cells is not the only etiopathogenic factor in autoimmunity (93) and the thymic $T$ cell negative selection is not a perfect mechanism (94). Nevertheless, it is the only one for which the precise description of the underlying molecular mechanisms should allow novel diagnostic and preventive therapeutic intervention. Another important conclusion which can be drawn from our work is the fact that the thymus is not the site for the expression of all neuropeptide genes, but apparently only of the genes coding for representative members of neuroendocrine families. Although fundamental, the central immune tolerance of neuroendocrine functions does not of course exclude the possibility of other peripheral tolerogenic mechanisms, as recently demonstrated by the inhibition of the diabetogenic process in NOD mice fed with heterologous insulin (95). This observation is another indication that the whole peripheral $T$ cell repertoire is not shaped by self antigens alone, but that environmental factors may also contribute to this fundamental process. This latter point has already been shown for non-inherited maternal HLA antigens (96). As already shown, new immunomodulating strategies may be designed on the pharmacological manipulation of the cryptocrine signalling (45). Innovative testing procedures for the detection of high-risk patients and preventive therapeutics of endocrine autoimmune disorders may also be constructed on our model of the thymic repertoire of neuroendocrine self antigens.

\section{ACKNOWLEDGMENTS}

Vincent Geenen is Research Associate of the National Fund of Scientific Research (Belgium); Françoise Robert is Chargé de Recherches 1ère Classe of INSERM (France). This work is supported by the Special Funds for Scientific Research of the University of Liège and Liège Medical School, by the Association Française contre les Myopathies, by the Belgian Fund for Medical Scientific Research (grants $n^{\circ} 3.4562 .90$ and 7.4611.91), by the Ministère de la Région Wallonne (DGTR), and by the European Science Foundation (Neuroimmunomodulation Network). This work was awarded by the SmithKline Beecham Prize for Scientific Research (1989-1991) selected by the Royal Academy of Medicine of Belgium (1992). 


\section{REFERENCES}

1. Miller J.F.A.P., Osoba D.

Current concepts of the immunological function of the thymus.

Physiol. Rev. 47: 437, 1967.

2. Bauvois B., Ezine S., Imhof B.A., Denoyelle M., Thiery J.P.

A role for thymic epithelium in the selection of pre-T cells from murine bone marrow.

J. Immunol. 143: 1077, 1989.

3. Ritter M.A., Crispe I.N.

The thymus.

IRL Press, In Focus Series, Oxford, 1992.

4. Davis M.M., Bjorkman P.J.

T-cell antigen receptor genes and T-cell recognition. Nature 334: 395, 1988.

5. Blackman M.A., Kappler J., Marrack P. T-cell specificity and repertoire.

Immunol. Rev. 101: 5, 1988.

6. von Boehmer H., Kisielow P.

Self-nonself discrimination by $T$ cells.

Science 248: 1369, 1990.

7. Tentori L., Pardoll D.M., Zuniga J.C., Hu-Li J., Paul W.E., Bluestone J.A., Kruisbeek A.M.

Proliferation and production of IL-2 and B cell stimulatory factor $1 / \mathrm{IL}-4$ in early fetal thymocytes by activation through Thy- 1 and CD3.

J. Immunol. 140: 1089, 1988.

8. Sprent J., Lo D., Gao E.K., Ron Y.

T cell selection in the thymus.

Immunol. Rev. 101: 5, 1988.

9. von Gaudecker B.

Functional histology of the human thymus.

Anat. Embryol. (Berl.) 183: 1, 1991.

10. Norris E.H.

The morphogenesis and histogenesis of the thymus gland in man: In which the origin of the Hassall's corpuscles of the human thymus is discovered.

Carnegie Inst. Wash. Publ. n496, Contrib. Embryol. 27: 191, 1938.

11. Cordier A.C., Haumont S.M.

Development of thymus, parathyroids, and ultimobranchial bodies in NMRI and nude mice.

Am. J. Anat. 157: 227, 1980.

12. Le Douarin N.M., Jotereau F.V.

Tracing of cells of the avian thymus through embryonic life in interspecific chimeras.

J. Exp. Med. 142: 17, 1975.

13. Haynes B.F., Shimizu K., Eisenbarth G.S. Identification of human and rodent thymus epithelium using tetanus toxin and monoclonal antibody A2B5.

J. Clin. Invest. 71: 9, 1983.

14. Savino W., Dardenne M., Papiernik M., Bach J.F. Thymic hormone-containing cells. Characterization and localization of serum thymic factor in young mouse thymus studied by monoclonal antibodies.

J. Exp. Med. 156: 628, 1982.
15. Eisenbarth G.S., Walsh F.S., Nirenberg M.

Monoclonal antibody to a plasma membrane antigen of neurons.

Proc. Natl. Acad. Sci. USA 76: 4913, 1979.

16. Geenen V., Legros J.J., Franchimont P., Defresne M.P., Boniver J., Ivell R., Richter D.

The thymus as a neuroendocrine organ. Synthesis of vasopressin and oxytocin in human thymic epithelium.

Ann. N.Y. Acad. Sci. 496: 56, 1987.

17. Robert F., Geenen V., Schoenen J., Burgeon E., De Groote D., Defresne M.P., Legros J.J., Franchimont P. Colocalization of immunoreactive oxytocin, vasopressin and interleukin-1 in human thymic epithelial neuroendocrine cells.

Brain Behav. Immun. 5: 102, 1991.

18. Wekerle H., Ketelsen U.P.

Thymic nurse cells. la-bearing epithelium involved in T-lymphocyte differentiation?

Nature 283: 402, 1980.

19. Defresne M.P., Goffinet G., Boniver J.

In situ characterization in freeze-fractured mouse thymuses of lympho-epithelial complexes ultrastructurally similar to isolated thymic nurse cells.

Tissue Cell 18: 321, 1986.

20. van Ewijk W.

Cell surface topography of thymic microenvironments.

Lab. Invest. 59: 579, 1988.

21. Geenen V., Defresne M.P., Robert F., Legros J.J., Franchimont P., Boniver J.

The neurohormonal thymic microenvironment: immunocytochemical evidence that thymic nurse cells are neuroendocrine cells.

Neuroendocrinology 47: 365, 1988.

22. Nabarra B., Andrianarison 1.

Pattern of secretion in thymic epithelial cells: ultrastructural studies of the effect of blockade at various levels.

Cell Tissue Res. 249: 171, 1987.

23. Funder J.W.

Paracrine, cryptocrine, acrocrine.

Mol. Cell. Endocrinol. 70: C21, 1990.

24. Peter K.

Die Bedeutung der Nahrzelle im Hoden.

Areh. Mikrosk. Anat. 55: 180, 1899.

25. Marrak P., McCormak J., Kappler J.

Presentation of antigen, foreign major histocompatibility complex proteins and self by thymus cortical epithelium.

Nature 338: 503, 1989.

26. Kyewsky B.A.

Thymic nurse cells: possible sites of $T$ cell selection. Immunol. Today 7: 374, 1986.

27. Salaün J.C., Bandeira A., Khazaai I., Calman F., Coltey M., Coutinho A., Le Douarin N.M. 
Thymic epithelium tolerizes for histocompatibility antigens.

Science 247: 147 1, 1990.

28. Good M.F., Pyke K.W., Nossal G.J.V.

Functional deletion of cytotoxic T-lymphocyte precursors in chimeric thymus produced in vitro from embryonic Anlagen.

Proc. Natl. Acad. Sci. USA 80: 3045, 1983.

29. Webb S.R., Sprent J.

Tolerogenecity of thymic epithelium.

Eur. J. Immunol. 20: 2525, 1990.

30. Geenen V., Robert F., Martens H., Benhida A., De Giovanni G., Defresne M.P., Boniver J., Legros J.J., Martial J., Franchimont P.

Biosynthesis and paracrine/cryptocrine actions of self neurohypophysial-related peptides in the thymus.

Mol. Cell. Endocrinol. 76: C27, 1991.

31. Ang H.L., Ungefroren H., De Bree F., Foo N.C., Carter D., Burbach J.P.H., Ivell R., Murphy D.

Testicular oxytocin gene expression in seminiferous tubules of cattle and transgenic mice.

Endocrinology 128: 2110, 1991.

32. Burgeon E., Chapleur M., Schoenen J., Remichius D., Legros J.J., Geenen V., Robert F.

Monoclonal antibodies to oxytocin: production and characterization.

J. Neuroimmunol. 31: 235, 1991.

33. Argiolas A., Melis M.R., Stancampiano R., Mauri A., Gessa G.L.

Hypothalamic modulation of immunoreactive oxytocin in the rat thymus.

Peptides 11: 539, 1990.

34. Argiolas A., Gessa G.L., Melis M.R., Stancampiano R., Vaccari A.

Effects of neonatal and adult thyroid dysfunction on thymic oxytocin.

Neuroendocrinology 52: 556, 1990.

35. Jevremovic M., Barbijeri M., Kovacevic D., Arambasic M., Kartaljevic G., Natalic D.J., Pazin S. Identification of neuroendocrine oxytocic activity of the human fetal thymus.

Thymus 15: 181, 1990.

36. Elands J., Resink A., de Kloet E.R.

Neurohypophyseal hormone receptors in the rat thymus, spleen, and lymphocytes.

Endocrinology 126: 2703, 1990.

37. Martens H., Robert F., Legros J.J., Geenen V., Franchimont $P$.

Expression of functional neurohypophysial peptide receptors by murine immature and cytotoxic $T$ cell lines.

Prog. Neuro. Endocrin. Immunol. 5: 31, 1992.

38. Geenen V., Robert F., Fatemi M., Defresne M.P., Boniver J., Legros J.J., Franchimont P.

Vasopressin and oxytocin: thymic signals and receptors in T cell ontogeny.

In: Yoshida S., Share L. (Eds.), Recent progress in posterior pituitary hormones.

Elsevier, New York, 1988, p. 303.
39. Morel A., O'Carroll A.M., Brownstein M.J., Lolait S.J. Molecular cloning and expression of a rat $\mathrm{V} 1 \mathrm{a}$ arginine vasopressin receptor.

Nature 356: 523, 1992.

40. Torres B.A., Johnson H.M.

Arginine vasopressin (AVP) replacement of helper cell requirement in IFN-g production. Evidence for a novel AVP receptor on mouse lymphocytes.

J. Immunol. 140: 2179, 1988.

41. Nikolic-Zugic J., Bevan M.J.

Role of self peptides in positively selecting the $T$ cell repertoire.

Nature 344: 65, 1990.

42. Rosai J., Levine G.D., Weber W.R., Higa E.

Carcinoid tumors and oat cell carcinomas of the thymus.

Pathol. Annu. 95: 5, 1976.

43. Giraud F., Fabien N., Auger C., Girod C., Loire R., Monier J.C.

Human epithelial thymic tumours: heterogeneity in immunostaining of epithelial cell markers and thymic hormones.

Thymus 15: 15, 1990.

44. Defresne M.P., Rongy A.M., Boniver J.

Cellular aspects of radiation leukemogenesis in C57B1/Ka mice.

II. Thymic microenvironment and nurse cells.

Leuk. Res. 10: 783, 1986.

45. Geenen V., Martens H., Robert F., Vrindts-Gevaert Y., De Groote D., Bock M.G., Freidinger R.M., Franchimont $P$.

Immunomodulatory properties of cyclic hexapeptide oxytocin antagonists.

Endocrine Society, 74th Annual Meeting, San Antonio (TX), 1992.

46. Ayer-LeLièvre C., Olson L., Ebendal T., Halbook F., Persson $\mathrm{H}$.

Nerve growth factor mRNA and protein in the testis and epididimis of the mouse and rat.

Proc. Natl. Acad. Sci. USA 85: 2628, 1988.

47. Persson H., Ayer-LeLièvre C., Soder O., Villar M.J., Metsis M., Olson L., Ritzen M., Hokfelt T.

Expression of B-nerve growth factor receptor mRNA in Sertoli cells downregulated by testosterone.

Science 247: 704, 1990.

48. Enrfors P., Hallbook F., Ebendal T., Shooter E.M., Radeke M.J., Misko T.P., Persson H.

Developmental and regional expression of $B$-nerve growth factor mRNA in the chick and rat.

Neuron 1: 983, 1988.

49. Screpanti I., Meco D., Scarpa S., Morrone S., Frati L., Gulino A., Modesti A.

Neuromodulatory loop mediated by nerve growth factor and interleukin 6 in thymic stromal cell cultures.

Proc. Natl. Acad. Sci. USA 89: 3209, 1992.

50. Robert F.R., Martens H., Cormann N., Benhida A., Schoenen J., Geenen V. 
The recognition of hypothalamo-neurohypophysial functions by developing $T$ cells.

Dev. Immunol. 2: 131, 1992.

51. Ivell R., Burbach J.P.H.

The molecular biology of vasopressin and oxytocin genes.

J. Neuroendocrinol. 3: 583, 1991.

52. Reddehase M.J., Rothbard J.B., Koszinowski U.H. A pentapeptide as minimal antigenic determinant for MHC class I-restricted T Iymphocytes.

Nature 337: 651, 1989.

53. Rudensky A.Y., Preston-Hulburt P., Hong S.C., Barlow A., Janeway C.A.Jr.

Sequence analysis of peptides bound to $\mathrm{MHC}$ class II molecules.

Nature 353: 622, 1991.

54. Scherbaum W.A., Bottazzo G.F., Czernichow P., Wass J.A.H., Doniach D.

Role of autoimmunity in central diabetes insipidus. Front. Horm. Res. 13: 232, 1985.

55. Cau P., Rougon-Capuzzi G.

Autoimmune alterations in the neurohypophysis of rabbits immunized against vasopressin.

Brain Res. 177: 265, 1979.

56. Geenen V., Legros J.J., Franchimont P., Baudrihaye M., Defresne M.P., Boniver J.

The neuroendocrine thymus: coexistence of oxytocin and neurophysin in the human thymus.

Science 232: 508, 1986.

57. Kourilsky P., Chaouat G., Rabourdin-Combe C., Claverie J.M.

Working principles in the immune system implied by the "peptidic self" model.

Proc. Natl. Acad. Sci. USA 84: 3400, 1987.

58. Geenen V., Robert F., Ericsson A., Persson H.

Thymus gland, Neuroendocrinology.

In: Smith B., Adelman G. (Eds.), Neuroscience Year.

Suppl. to the Encyclopedia of Neuroscience.

Birkhaüser, Boston, 1992, p. 149.

59. Ericsson A., Geenen V., Robert F., Legros J.J., Vrindts-Gevaert Y., Franchimont P., Brene S., Persson $\mathrm{H}$.

Expression of preprotachykinin-A and neuropeptide-

$Y$ messenger RNA in the thymus.

Mol. Endocrinol. 4: 1211, 1990.

60. Sader O., Hellström P.

The tachykinins neurokinin A and physalaemin stimulate murine thymocyte proliferation.

Int. Arch. Appl. Immunol. 90: 91, 1989.

61. Lorton D., Bellinger D.L., Felten S.Y., Felten D.L.

Substance $P$ innervation of the rat thymus.

Peptides 11: 1269, 1990.

62. Shigematsu K., Saavedra J.M., Kurihara M.

Specific substance $P$ binding sites in rat thymus and spleen: in vitro autoradiographic study.

Regul. Pept. 16: 147, 1986.

63. Han V.K.M., D'Ercole A.J., Lund P.K.
Cellular localization of somatomedin (insulin-like growth factor) messenger RNA in the human fetus. Science 286: 193, 1987.

64. Han V.K.M., Hill D.J., Strain A.J., Towie A.C., Lauder J.M., Underwood L.E., D'Ercole J.

Identification of somatomedin/insulin-like growth factor immunoreactive cells in the human fetus.

Pediatr. Res. 22: 245, 1987.

65. Gjerset R.A., Yeargin J., Volkman S.K., Vila V., Arya J., Haas M.

Insulin-like growth factor-1 supports proliferation of autocrine thymic lymphoma cells with a pre-T cell phenotype.

J. Immunol. 145: 3497, 1990.

66. Johnson E.W., Jones L.A., Kozak R.W.

Expression and function of insulin-like growth factor receptors on anti-CD3-activated human T Iymphocytes.

J. Immunol. 148: 63, 1992.

67. Julier C., Hyer R.N., Davies J., Merlin F., Soularue P., Briant L., Cathelineau G., Deschamps I., Rotter J.I., Froguel P., Boitard C., Bell J.I., Lathrop G.M. Insulin-IGF2 region on chromosome 11p encodes a gene implicated in HLA-DR4-dependent diabetes susceptibility.

Nature 354: 155, 1991.

68. Dotta F., Nayak R.C., Dib S.A., Di Bella E., Krisch K., Posillico J.T., Ricker A.T., Di Mario U., Eisenbarth G.S.

A novel neuroendocrine cell surface glycoprotein: identification, isolation, and initial characterization. Endocrinology 122: 1263, 1988.

69. Teitelman G.

Cellular and molecular analysis of pancreatic islet cell lineage and differentiation.

Recent Prog. Horm. Res. 47: 258, 1991.

70. Millington G., Buckingham J.C.

Thymic peptides and neuroendocrine-immune communication.

J. Endocrinol. 133: 163, 1992.

71. Fuller P.J., Verity K.

Somatostatin gene expression in the thymus gland J. Immunol. 143: 1015, 1989

72. Vollmar A., Schulz R.

Atrial natriuretic peptide is synthesized in the human thymus.

Endocrinology 126: 2277, 1990.

73. Lauriola L., Maggiano N., Larocca L.M., Ranelletti F.O., Ricci R., Piantelli M., Capelli A.

Cells immunoreactive for neuropeptide in human thymomas.

J. Clin. Pathol. 43: 829, 1990.

74. Fukayama M., Hayashi Y., Shiozawa Y., Maeda Y., Koike M.

Human chorionic gonadotrophin in the thymus.

Am. J. Pathol. 136: 123, 1990.

75. Redei E. 
Immuno-reactive and bioactive corticotropin-releasing factor in rat thymus.

Neuroendocrinology 55: 115, 1992.

76. Kurihara M., Katamine S., Saavedra J.M.

Atrial natriuretic peptide, ANP (99-126), receptors in rat thymocytes and spleen cells.

Biochem. Biophys. Res. Commun. 145: 789, 1987.

77. Marchetti B., Guarcello V., Morale M.C., Bartoloni G., Farinella Z., Cordaro S., Scapagnini U.

Luteinizing hormone-releasing hormone-binding sites in the rat thymus: characteristics and biological function.

Endocrinology 125: 1025, 1989.

78. Marchetti B., Guarcello V., Morale M.C., Bartoloni G., Raiti F., Palumbo G. Jr., Farinella Z., Cordaro S., Scapagnini U.

Luteinizing hormone-releasing hormone (LHRH) agonist restoration of age-associated decline of thymus weight, thymic LHRH receptors, and thymocyte proliferation capacity.

Endocrinology 125: 1037, 1989.

79. Kramer S., Reynolds F.H.Jr., Castillo M., Valenzuela D.M., Thorikay M., Sorvillo J.M.

Immunological identification and distribution of parathyroid hormone-like protein polypeptide in normal and malignant tissues.

Endocrinology 128: 1927, 1991.

80. Bulloch K., Radjocic T., Yu R., Hausman J., Lenhard L., Baird S.

The distribution and function of calcitonin gene-related peptide in the mouse thymus and spleen.

Prog. Neuro. Endocrin. Immunol. 4: 186, 1991.

81. Bulloch $\mathrm{K}$.

Neuroanatomy of lymphoid tissue: a review.

In: Guillemin R., Cohn M., Melnechuk T. (Eds.),

Neural modulation of immunity.

Raven Press, New York, 1985, p. 111.

82. Williams J.M., Felten D.L.

Sympathetic innervation of murine thymus and spleen: a comparative histofluorescence study.

Anat. Rec. 199: 53, 1981.

83. Kendall M.D., Al-Shawaf A.A.

Innervation of the rat thymus gland.

Brain Behav. Immun. 5: 9, 1991.

84. Fabris N., Mocheggiani M., Mariotti S., Pacini F., Pinchera A.

Thyroid function modulates thymic endocrine activity.

J. Clin. Endocrinol. Metab. 62: 474, 1986.

85. Dardenne M., Savino W.

Neuroendocrine control of the thymic epithelium: modulation of thymic endocrine function, cytokeratin expression and cell proliferation by hormones and neuropeptides.

Prog. Neuro. Endocrin. Immunol. 3: 18, 1990.

86. Dardenne M., Savino W., Duval D., Kaiserlian D., Hassid J., Bach J.F.

Thymic hormone-containing cells. VII. Adrenals and gonads control the in vivo secretion of thymulin and its plasmatic inhibitor.

J. Immunol. 136: 1303, 1986.

87. Grossman C.J., Nathan P., Taylor B.B., Sholiton L.J. Rat thymic dihydrotestosterone receptor: preparation, localization and physical properties.

Steroids 34: 539, 1979.

88. Stites D.P., Siiteri P.K.

Steroids as immunosuppressants in pregnancy. Immunol. Rev. 75: 117, 1983.

89. Kelley K.W., Brief S., Westly H.J., Novakofski J., Bechtel P.J., Simon J., Walker E.R.

GH3 pituitary adenoma cells can reverse thymic aging in rats.

Proc. Natl. Acad. Sci. USA 83: 5663, 1986.

90. Berczi I.

Pituitary function and immunity.

CRC Press, Boca Raton, 1986.

91. Geenen V., Martens H., Robert F., Legros J.J., Defresne M.P., Boniver J., Martial J., Lefèbvre P.J., Franchimont $P$.

Thymic cryptocrine signalling and the immune recognition of self neuroendocrine functions.

Prog. Neuro. Endocrin. Immunol. 4: 135, 1991.

92. Ellis R.E., Yuan J., Horvitz H.R.

Mechanisms and functions of cell death.

Annu. Rev. Cell Biol. 7: 663, 1991.

93. Naquet P., Ellis J., Tibensky D., Kenshole A., Singh B., Hodges R., Delovitch T.L.

T cell autoreactivity to insulin in diabetic and related nondiabetic individuals.

J. Immunol. 140: 2569, 1988.

94. von Boehmer H., Kirberg J., Rocha B.

An unusual lineage of $\alpha / \beta$ T cells that contains autoreactive cells.

J. Exp. Med. 174: 1001, 1991.

95. Zhang Z.J., Davidson L., Eisenbarth G., Weiner H.L. Suppression of diabetes in nonobese diabetic mice by oral administration of porcine insulin.

Proc. Natl. Acad. Sci. USA 88: 10252, 1991.

96. Zhang L., van Rood J.J., Claas F.H.J.

The T cell repertoire is not dictated by self antigens alone.

Res. Immunol. 142: 441, 1991. 